\title{
Alectinib as a treatment option following recovery from crizotinib-induced interstitial lung disease in patients with anaplastic lymphoma kinase-positive advanced non-small-cell lung cancer
}

\author{
SHIGENARI NUKAGA ${ }^{1}$, KATSUHIKO NAOKI $^{1,2}$, TETSURO KAMO $^{1}$, KEITA MASUZAWA $^{1}$, \\ HIROYUKI YASUDA $^{1}$, KENZO SOEJIMA ${ }^{1}$ and TOMOKO BETSUYAKU ${ }^{1}$ \\ ${ }^{1}$ Division of Pulmonary Medicine, Department of Medicine; ${ }^{2}$ Cancer Center, \\ Keio University School of Medicine, Tokyo 160-8582, Japan
}

Received November 3, 2015; Accepted March 21, 2016

DOI: $10.3892 / \operatorname{mco} .2016 .838$

\begin{abstract}
Crizotinib is a tyrosine kinase inhibitor that displays antitumor activity against anaplastic lymphoma kinase $(A L K)$-positive advanced non-small-cell lung cancer. However, crizotinib-associated interstitial lung disease (ILD) has been reported as an infrequent, but potentially fatal complication. We herein describe the case of a 63 -year-old male patient with $A L K$-rearranged advanced lung adenocarcinoma. Chest computed tomography (CT) revealed extensive bilateral ground-glass opacity and airspace consolidation with traction bronchiectasis on day 27 of crizotinib therapy. No signs of infection or left heart failure were identified and we considered the lesions to be consistent with crizotinib-induced ILD. Following corticosteroid treatment and discontinuation of crizotinib, $\mathrm{CT}$ revealed improvement of ILD, but also showed regrowth of the tumor. Alectinib, a novel alternative ALK inhibitor, was initiated, and has been successfully continued, with neither disease progression nor recurrence of ILD. The present case indicates that alectinib may be considered as an alternative agent in cases of crizotinib-induced ILD, irrespective of the pattern of ILD, i.e., a diffuse alveolar damage (DAD) or non-DAD pattern, with careful observation.
\end{abstract}

\section{Introduction}

Crizotinib is a tyrosine kinase inhibitor that has antitumor activity against anaplastic lymphoma kinase ( $A L K)$-positive advanced non-small-cell lung cancer (NSCLC) (1). However,

Correspondence to: Dr Katsuhiko Naoki, Cancer Center, Keio University School of Medicine, 35 Shinanomachi, Shinjuku, Tokyo 160-8582, Japan

E-mail:knaoki@pg7.so-net.ne.jp

Key words: non-small-cell lung cancer, anaplastic lymphoma kinase, interstitial lung disease, crizotinib, alectinib crizotinib-associated interstitial lung disease (ILD) has been reported as an infrequent but potentially fatal complication $(2,3)$.

Alectinib is a novel oral ALK inhibitor with high potency and selectivity for ALK, which displays promising antitumor activity in NSCLC. Alectinib has shown promising activity in patients with crizotinib-resistant disease and has been generally well-tolerated in clinical trials $(4,5)$. The safety of alectinib for patients who develop crizotinib-induced ILD has not been determined. We herein describe a case of $A L K$-positive NSCLC successfully treated with alectinib after developing crizotinib-induced ILD.

\section{Case report}

A 63-year-old Japanese man with a 25 pack-year smoking history presented with a 4-month history of cough. The patient was diagnosed with advanced lung adenocarcinoma (cT4N3M1b), with bone, brain and multiple lymph node metastases (Fig. 1A). Fluorescence in situ hybridization analysis revealed the presence of $A L K$ gene rearrangement. Crizotinib (250 mg twice daily) was administered as first-line chemotherapy. On day 27, the patient developed high-grade fever and exertional dyspnea. Chest computed tomography (CT) revealed a decrease in tumor size; however, there was new extensive bilateral ground-glass opacity (GGO) and airspace consolidation with traction bronchiectasis (Fig. 1B). With the patient on oxygen at a flow rate of $51 / \mathrm{min}$ via a mask, the arterial blood gas analysis revealed a $\mathrm{PaO}_{2}$ of $48.5 \mathrm{mmHg}$. Although the chest CT revealed bilateral pleural effusions, there was no evidence of left heart failure. There were also no signs of infection. Based on these findings, crizotinib-induced ILD was suspected. Crizotinib was discontinued immediately, and methylprednisolone pulse therapy ( $1 \mathrm{~g} /$ day for 3 days) followed by oral prednisolone (PSL) at a dose of $65 \mathrm{mg} /$ day was initiated. Given that the patient's symptoms and radiological findings improved, the PSL dose was gradually tapered. Ten weeks after crizotinib was discontinued, the PSL dose was decreased to $25 \mathrm{mg} /$ day. The chest $\mathrm{CT}$ showed no recurrence 
A

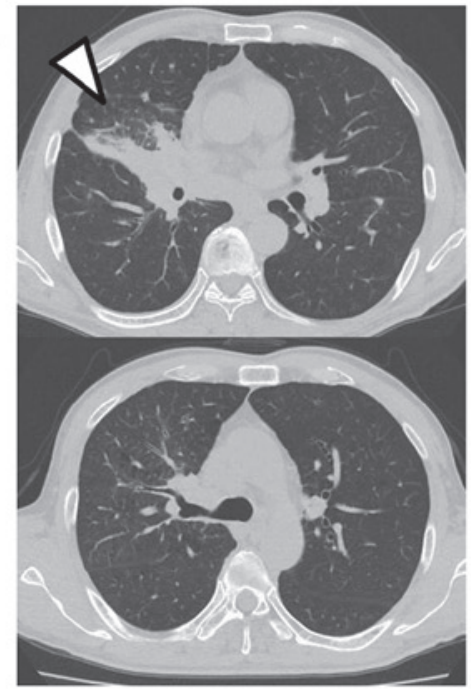

$\mathbf{C}$

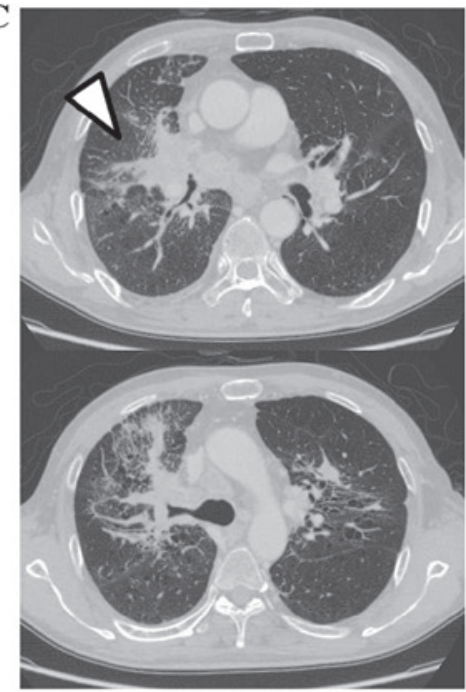

B
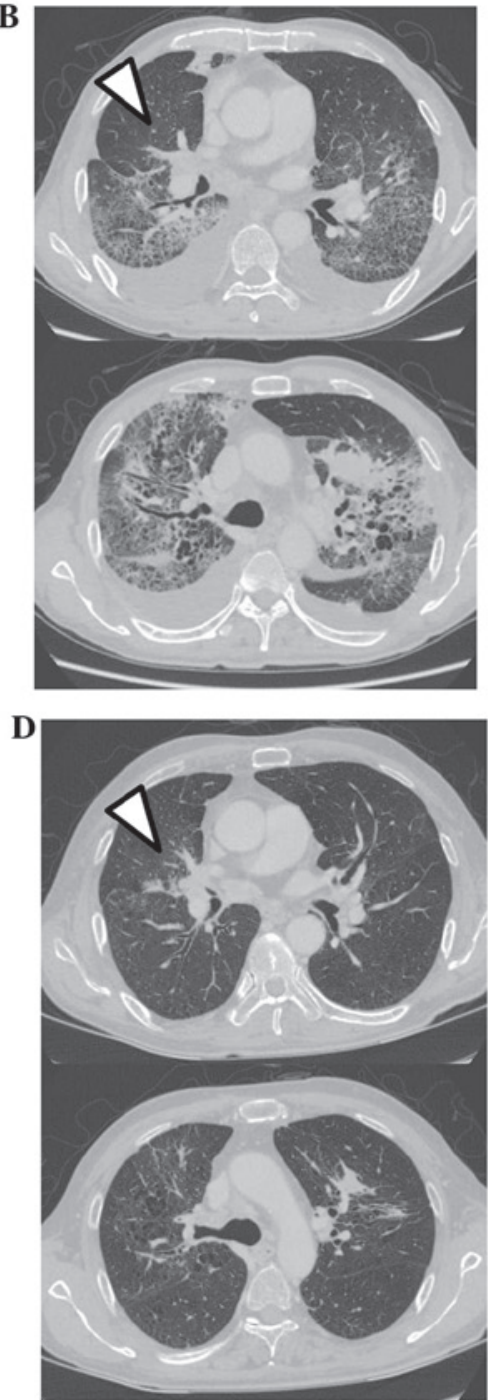

Figure 1. (A) Prior to treatment with crizotinib, chest CT revealed a mass in the middle lobe of the right lung. (B) One month after initiation of crizotinib, the chest CT revealed a decrease in the size of the tumor, but there was extensive bilateral GGO, airspace consolidation with traction bronchiectasis, and bilateral pleural effusion. (C) After treatment with prednisolone and discontinuation of crizotinib, the chest CT showed improvement of ILD, but also regrowth of the tumor. (D) Four months after initiation of alectinib, CT showed good response without recurrence of ILD. The tumor location is indicated by the arrowheads CT, computed tomography; GGO, ground-glass opacity; ILD, interstitial lung disease.

of ILD, but the primary lesion had regrown (Fig. 1C). After discussing the risk of ILD exacerbation and obtaining the patient's informed consent, alectinib (300 mg twice daily) was initiated. After 2 weeks, the primary lesion had decreased in size, without any exacerbation of the ILD. The patient received continuous alectinib treatment, with neither disease progression nor recurrence of ILD for more than 4 months, without the need for steroid therapy (Fig. 1D).

\section{Discussion}

Treatment with the first-generation ALK inhibitor crizotinib is associated with a risk of ILD development. ILD, which may be severe and occasionally fatal $(2,3)$, develops in $2 \%$ of the cases. Crizotinib-induced ILD may present with at least two types of radiological findings, namely as the 'diffuse alveolar damage (DAD) pattern' and the 'hypersensitivity pneumonia (HP) pattern' (6). The DAD pattern is severe and fatal in most cases. Chest CT shows a rapid, bilateral and widespread development of GGO. The HP pattern is less severe and may not be associated with a definitive need for crizotinib withdrawal. Chest CT shows a predominant GGO pattern, which is localized and faint. Some cases of successful crizotinib retreatment after crizotinib-induced ILD have been reported, but they all had the non-DAD pattern (6,7). Retreatment with crizotinib should be avoided in patients with the DAD pattern, as the mortality rate of such patients is very high.

While crizotinib is a multitargeted inhibitor of the ALK, MET, and ROS1 receptor tyrosine kinases $(8,9)$, alectinib is highly selective for ALK. The high selectivity for ALK may contribute to its reduced toxicity compared with crizotinib (4). We were able to successfully treat our patient, who had developed a crizotinib-induced DAD pattern of ILD, with alectinib. Therefore, alectinib may be considered as an alternative agent in cases of crizotinib-induced ILD, irrespective of the pattern of ILD, i.e., a DAD or non-DAD pattern, with careful observation. 


\section{References}

1. Kwak EL, Bang YJ, Camidge DR, Shaw AT, Solomon B, Maki RG, Ou SH, Dezube BJ, Jänne PA, Costa DB, et al: Anaplastic lymphoma kinase inhibition in non-small-cell lung cancer. N Engl J Med 363: 1693-1703, 2010.

2. Shaw AT, Kim DW, Nakagawa K, Seto T, Crinó L, Ahn MJ, De Pas T, Besse B, Solomon BJ, Blackhall F, et al: Crizotinib versus chemotherapy in advanced ALK-positive lung cancer. N Engl J Med 368: 2385-2394, 2013.

3. Tamiya A, Okamoto I, Miyazaki M, Shimizu S, Kitaichi M and Nakagawa K: Severe acute interstitial lung disease after crizotinib therapy in a patient with EML4-ALK-positive non-small-cell lung cancer. J Clin Oncol 31: e15-e17, 2013.

4. Seto T, Kiura K, Nishio M, Nakagawa K, Maemondo M, Inoue A, Hida T, Yamamoto N, Yoshioka H, Harada M, et al: CH5424802 (RO5424802) for patients with ALK-rearranged advanced non-small-cell lung cancer (AF-001JP study): A single-arm, open-label, phase 1-2 study. Lancet Oncol 14: 590-598, 2013.

5. Gadgeel SM, Gandhi L, Riely GJ, Chiappori AA, West HL, Azada MC, Morcos PN, Lee RM, Garcia L, Yu L, et al: Safety and activity of alectinib against systemic disease and brain metastases in patients with crizotinib resistant ALK-rearranged non-small-cell lung cancer (AF-002JG): Results from the dose-finding portion of a phase $1 / 2$ study. Lancet Oncol 15: $1119-1128,2014$
6. Créquit P, Wislez M, Fleury Feith J, Rozensztajn N, Jabot L, Friard S, Lavole A, Gounant V, Fillon J, Antoine M and Cadranel J: Crizotinib associated with ground-glass opacity predominant pattern interstitial lung disease: A retrospective observational cohort study with a systematic literature review. J Thorac Oncol 10: 1148-1155, 2015.

7. Yanagisawa S, Inoue A, Koarai A, Ono M, Tamai $\mathrm{T}$ and Ichinose M: Successful crizotinib retreatment after crizotinib-induced interstitial lung disease. J Thorac Oncol 8: e73-e74, 2013.

8. Christensen JG, Zou HY, Arango ME, Li Q, Lee JH, McDonnell SR, Yamazaki S, Alton GR, Mroczkowski B and Los G: Cytoreductive antitumor activity of PF-2341066, a novel inhibitor of anaplastic lymphoma kinase and c-Met, in experimental models of anaplastic large-cell lymphoma. Mol Cancer Ther 6: 3314-3322, 2007.

9. Bergethon K, Shaw AT, Ou SH, Katayama R, Lovly CM, McDonald NT, Massion PP, Siwak-Tapp C, Gonzalez A, Fang R, et al: ROS1 rearrangements define a unique molecular class of lung cancers. J Clin Oncol 30: 863-870, 2012. 